\title{
ANATOMIA E ONTOGENIA DE GALHAS FOLIARES DE PIPTADENIA GONOACANTHA (FABALES, MIMOSACEAE) ${ }^{1}$
}

\author{
MARCOS ARDUIN* E JANE ELIZABETH KRAUS**
}

\author{
* Departamento de Botânica, Universidade Federal de São Carlos. C. Postal 676, \\ 13005-905, São Carlos, SP, Brasil. \\ **Instituto de Biociências, Universidade de São Paulo. C. Postal I 1461, 05422-970, \\ São Paulo, SP, Brasil.
}

\begin{abstract}
Anatomy and ontogeny of foliar galls on Piptadenia gonoacantha (Fabales, Mimosaceae)]. Thorny, red galls were observed on Piptadenia gonoacantha. Six stages were recognized during the gall development: 1) A small spot appears on one of the surfaces of the leaflet. A larval chamber lined by sclereids and surrounded by a parenchyma derived from chlorenchyma is formed; above the larval chamber roof, parenchymatic projections are formed. 2) The gall becomes a small red intumescence on the leaflet. The gall parenchyma increases and a cortical and a medullar regions are discernible. The medullar region is near to the larval chamber. 3 ) The gall becomes wrapped up by thorns; on the apex a tuft with long thorns is observed. In the beginning, cortical parenchyma increases, but latter its development ceases and then the medullar parenchyma begins to increase; the sclereids around the larval chamber desappear partially and a nutritive tissue is formed. 4) The gall elongates, assuming a conic shape. Sclereids are observed on the roof of larval chamber and the medullar parenchyma cells above it elongate. 5) The gall stops growing and the thorns spread uniformly around it. At first phase, the cells of the cortex-medullar transition region sclerify and the larva consumes the medullar cells. At the second phase, the larva consumes the medullar cells above larval chamber too, openning a exit channel toward the gall apex. At the third phase the larva returns to the larval chamber, that is incompletely divided in two sub-chambers by a sclerified septum, and stablishes itself in the pupal sub-chamber. The larva secretes a silky pelicle that prevents the entrance into the pupal sub-chamber. 6) An apperture appears apically (dehiscence) by desintegration of the remaining medullar cells, enlarging later. Senescent galls become dark and the original color change into brown, ending the cycle.
\end{abstract}

RESUMO - [Anatomia e ontogenia de galhas foliares de Piptadenia gonoacantha (Fabales, Mimosaceae)]. Em exemplares de Piptadenia gonoacantha foram observadas galhas espinhosas de cor predominantemente vermelha. Seis estádios de desenvolvimento foram definidos: 1) Observa-se uma pequena mancha numa das faces do foliólulo. Forma-se uma câmara larval revestida de esclereídes, a qual é envolvida por um parênquima derivado do clorênquima; acima do teto da câmara larval formam-se projeções parenquimáticas. 2) Observa-se um pequeno intumescimento avermelhado. O parênquima da galha aumenta, formando as regiões cortical e medular. A regiāo medular fica junto à câmara larval. 3) A galha aumenta em tamanho, cobre-se de espinhos e no ápice forma-se um tufo com espinhos mais longos que os laterais. O parênquima cortical aumenta primeiro, seguido depois pelo medular; as esclereídes que

\footnotetext{
${ }^{1}$ Parte da dissertação de mestrado apresentada ao Instituto de Biociências, USP, sob orientação da Dra J. E. Kraus.
} 
revestiam toda a câmara larval desaparecem em parte e instala-se o tecido nutritivo. 4) O corpo da galha assume um formato cônico. As esclereídes permanecem apenas no teto da câmara larval ce as células medulares situadas acima delas alongam-se bastante. 5) A galha pára de crescer e os espinhos distribuemse uniformemente. Na la fase, ocorre esclerificação das células na região de transição córtex-medula e a larva consome as células medulares até a zona esclerificada; na $2^{a}$ fase, a larva consome as células medulares situadas acima da câmara larval, construindo un canal de saída em direção ao ápice da galha; na $3^{\text {a }}$ fase, a larva retorna à câmara larval, que está dividida em duas sub-câmaras por um septo esclerificado incompleto. Instala-se na sub-câmara pupal, secretando um tabique de seda, que veda a entrada desta. 6) Forma-se uma abertura no ápice da gallha (deiscência) devido à desinteg̣ração das células medulares restantes. Esta abertura alarga-se posteriormente. As galhas senescentes ficam mais escuras e a cor original muda para uma cor castanha, terminando o ciclo.

Key-words: Leaf galls, Cecidomyiidae, Piptadenia gonoacantha.

\section{INTRODUÇÃO}

Tecidos vegetais podem ser atacados por patógenos, tais como vírus, micoplasmas, bactérias, fungos, nemátodos, ácaros ou insetos. Tal infecção pode resultar no desenvolvimento de galhas, que são estruturas anormais, não encontradas numa planta sadia (Mani 1964, Meyer \& Maresquelle 1983). O agente indutor, através de estímulos mecânicos e/ou químicos induz as células do tecido vegetal a se diferenciarem de forma atípica, levando à formação da galha (Meyer \& Maresquelle 1983).

Há abundante literatura disponível a respeito de estudos anatômicos e ontogenéticos em galhas das regiões temperadas, citando-se as revisões de Mani (1964), Meyer e Maresquelle (1983) e Rohfritsch (1992). No Brasil, a maioria dos trabalhos referese a breves descrições morfológicas ou a identificação dos indutores, muitas vezes sem uma identificação precisa da planta hospedeira (Fernandes \& Martins 1985). Raros são os trabalhos que abordam os estudos anatômicos e ontogenéticos de galhas e muitos deles são de acesso pouco fácil por se tratarem de teses ou dissertações. Dentre eles citam-se os de Neves (1987), Carrocini (1989), Arduin (1992) e Isaias (1992). Mais recentemente têm sido feitas algumas publicações sobre anatomia de galhas em espécimes brasileiros, como por exemplo Arduin et al. (1991) e Kraus et al. (1993).

O objetivo deste trabalho é fazer uma descrição anatômica e ontogenética de uma galha espinhosa, em Piptadenia gonoacantha (Mart.) Macbr. (Fabales, Mimosaceae), visando a obtenção de informações que possibilitem a compreensão dos processos morfogenéticos envolvidos no desenvolvimento desta galha.

\section{MATERIAIS E MÉTODOS}

Amostras do material botânico com ou sem galhas foram coletadas nos arredores da Reserva Ecológica da Cidade Universitária "Armando de Salles Oliveira" CUASO - (São Paulo, SP) no período de março de 1989 a janeiro de 1992. O material encontra-se depositado no Herbário do Departamento de Botânica do Instituto de Biociências da Universidade de São Paulo (SPF): Piptadenia gonoacantha (Mart.) Macbr. col. M. Arduin, 16-I-1991, SPF 82.220. 
Grupos de galhas em fases iniciais de desenvolvimento foram acompanhados até a fase adulta. Como a oviposição não foi observada, considerou-se como estádio inicial o mais jovem possível de ser obtido e que pudesse ser atribuído a essa galha.

Para o preparo de lâminas histológicas permanentes, o material foi submetido à fïxação em FAA (formaldeído 37-40\%, ácido acético glacial e álcool etílico $50 \%$, $1: 1: 18, \mathrm{v} / \mathrm{v})(\mathrm{Johansen} 1940)$, seguido do amolecimento em etilenodiamina a $10 \%$ por uma ou duas semanas (Carlquist 1982). A seguir procedeu-se à desidratação em série butílica terciária e infiltração em parafina ou "paraplast". Após o seccionamento do material ( $\pm 12 \mu \mathrm{m}$ de espessura), fez-se a afixação das tiras de parafina com adesivo de Bissing (Bissing 1974). Para a coloração dos cortes histológicos foi utilizado o método de Northen (1936) modificado com a utilização de fucsina básica e verdefirme. As lâminas foram montadas em bálsamo-de-canadá.

Em cortes obtidos à mão livre foram feitos testes com solução de cloreto férrico a 3\% para evidenciar substâncias fenólicas (Johansen 1940). Os taninos condensados foram fixados por FAA (Gardner 1975).

Para a análise de inclusões inorgânicas foram aplicados os seguintes testes: 1) ácido clorídrico a 10\% para evidenciar a presença de carbonato (Chamberlain 1932); 2) fenol, para evidenciar a sílica (Johansen 1940); e 3) água oxigenada $30 \%$ e nitrato de prata 5\% (1:1, v/v) para evidenciar oxalato de cálcio (Pizzolato 1964, Silver 1969).

Os aspectos mais relevantes dos materiais foram registrados em foto e estereomicroscópio.

\section{RESULTADOS}

Aspectos anatômicos dos foliólulos sadios

$\mathrm{O}$ aspecto geral do foliólulo de folha madura pode ser visto na figura la. Em corte transversal (Figs. la l e 3), observa-se que a epiderme adaxial (Ed) tem cutícula mais espessa e sua altura é duas vezes maior do que a da epiderme abaxial (Eb). Constatou-se acúmulo de substâncias fenólicas nas células epidérmicas. O parênquima paliçádico (PP) apresenta uma camada de células alongadas anticlinalmente e ocupa metade da altura do mesofilo. O parênquima esponjoso (PE) consiste de quatro a seis camadas de células que se situam em diferentes alturas. Os elementos condutores na nervura principal $(\mathrm{N})$ estão entremeados por células parenquimáticas, com o floema voltado para a epiderme abaxial e o xilema para a adaxial. Os feixes são circundados por fibras (Fb), cujo número de camadas é variável, conforme o tamanho da nervura. Na região próxima à epiderme abaxial pode haver três ou mais camadas de fibras, enquanto que nas regiões laterais apenas uma. Nos feixes vasculares maiores, as células da bainha (B) próximas às epidermes tornam-se esclerificadas (Fig. 4). O lume destas células é preenchido por cristais $(\mathrm{Cr})$ cúbicos ou romboédricos e apresentam uma fina camada de protoplasma. Os testes para corpos silicosos e para carbonato de cálcio foram negativos, mas foram positivos para o oxalato de cálcio. Há poucos canais de pontoação (seta) na parede das esclereídes, estabelecendo comunicação com as fibras do feixe. Não foi observada esclerificação nas células da bainha situadas 
lateralmente aos feixes. Nas nervuras menores a quantidade de fibras na região basal tende a diminuir e nas terminações não se observam fibras ou esclereídes na bainha.

\section{Aspectos anatômicos e ontogenéticos da galha}

As galhas ocorrem isoladamente mais frequientemente na epiderme abaxial e ocasionalmente na adaxial. Raramente ocorrem duas galhas opostas num mesmo foliólulo. A cor é predominantemente vermelha, podendo haver partes verdes, enquanto outras são totalmente verdes.

As galhas podem desenvolver-se em foliólulos de folhas maduras ou nos de folhas jovens, sem alteração de sua morfologia. Com base na anatomia, delimitou-se seis estádios de desenvolvimento. As descrições referentes aos aspectos anatômicos, a menos que se forneça outra indicação, basearam-se em cortes longitudinais medianos à galha. Deve-se considerar também que o desenvolvimento da galha é predominantemente no sentido acrópeto, tomando-se portanto como basal a região em contato com o foliólulo e como apical a região mais distanciada.

Estádio 1 - Em fase bem jovem, a galha mostra-se como um pequeno abaulamento de coloração vermelha (Fig. lb).

Em corte (Fig. l bl e 5), distinguem-se as regiões periféricas da galha e a região da galha propriamente dita. Nas regiões periféricas, as epidermes do foliólulo não se alteram; as células do parênquima paliçádico dividem-se e as do parênquima esponjoso alongam-se anticlinalmente, levando ao desaparecimento dos espaços intercelulares. Nos feixes vasculares ocorre proliferação do parênquima vascular e parte das fibras desintegra-se. Na região da galha, ao redor da câmara larval (Ca), as células componentes do clorênquima dividem-se, formando células parenquimáticas menores e isodiamétricas (seta). A câmara larval é relativamente ampla e dentro dela pode ser visto o indutor (I). Suas paredes são revestidas por duas camadas de esclereídes (Es), exceto numa região onde se observam pelo menos três camadas. Esta região foi denominada, pela sua posição, de teto da câmara larval (Te). Sobre este teto formamse projeções constituídas de células parenquimáticas (PrP). Algumas dessas células são iguais às que cercam a câmara larval, enquanto que outras são menores, com citoplasma denso, lembrando células meristemáticas. As projeções são revestidas por uma epiderme neoformada. $\mathrm{O}$ abaulamento visto externamente corresponde a estas projeções. Na porção interna das projeções, observam-se elementos condutores neoformados. Por entre as projeções há um canal que liga o teto da câmara larval com o exterior. Dentro do canal observam-se restos de um tecido não identificado. Estes aspectos sugerem que a oviposição, ou pelo menos a entrada da larva nos tecidos

Fig. 1 - Piptadenia gonoacantha (Mart.) Macbr. Diagrama representando o desenvolvimento das galhas. Estádios 1 a 4, mostrando aspectos externos à esquerda (a, b, c, d e e) e aspectos internos à direta (al, bl, $\mathrm{cl}, \mathrm{c} 2, \mathrm{dl}, \mathrm{d} 2, \mathrm{e}$ el).

Fig. 1 - Piptadenia gonoacantha (Mart.) Macbr. Diagram featuring of the gall development. Stages 1 to 4 , showing morphological aspects at left (a, b, c, d e e) and anatomical ones at right (al, bl, cl, c2, d1, d2, and $\mathrm{el}$ ). 


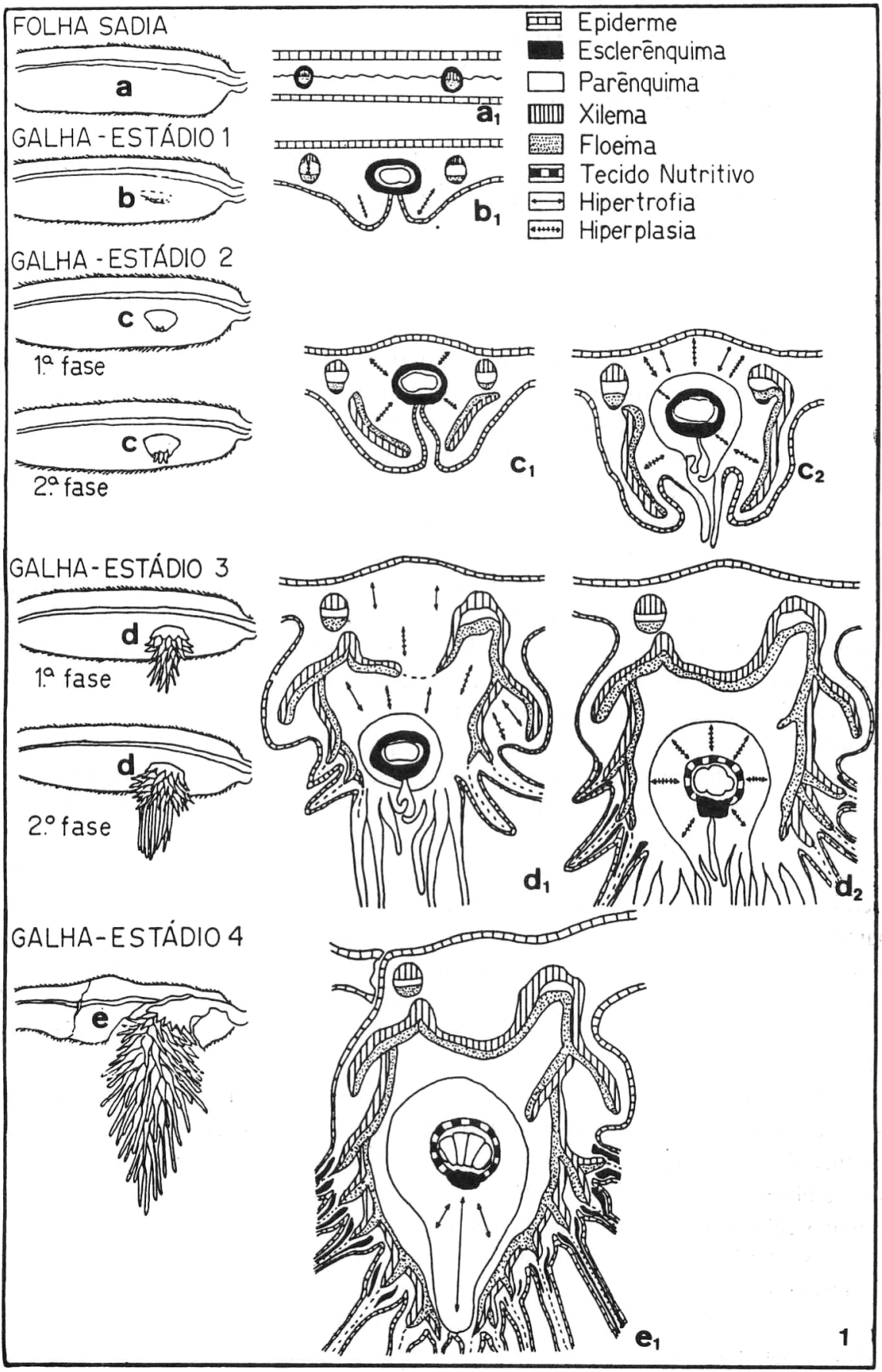


vegetais, poderia ter ocorrido neste local. Para efeito de orientação, este canal será chamado doravante de canal de oviposição $(\mathrm{CnO})$.

Estádio 2 - Neste estádio, o abaulamento apresenta um formato cônico e sobre ele forma-se um grupo congesto de espinhos pequenos, pouco nítidos a olho nu (Fig. $1 \mathrm{c}-1^{\mathrm{a}}$ fase e $2^{\mathrm{a}}$ fase).

Em corte observam-se várias mudanças neste estádio, distinguindo-se uma fase de desenvolvimento mais jovem (Figs. 1cl e 6) e uma mais avançada (Figs. 1c2 e 8). As células epidérmicas na face oposta ao canal de oviposição são isodiamétricas e, às vezes, apresentam os vacúolos preenchidos por um conteúdo denso (Fig. 9). Na epiderme da região do canal de oviposição (Fig. 7) observam-se tricomas tectores e tricomas capitados e com pedúnculo (setas). Nos tecidos parenquimáticos cecidiogênicos ocorre considerável proliferação celular (hiperplasia) e algumas células aumentam em tamanho (hipertrofia). As células periféricas constituem o córtex (Co) (Figs. 8 e 9) e apresentam o vacúolo volumoso e totalmente preenchido por substâncias fenólicas, que podem mostrar aspecto homogêneo (Cho)(Fig. 9) ou granulosos (Cg) (Fig. 10). Células parenquimáticas próximas aos feixes vasculares (Fig. 10) apresentam paredes finas, conteúdo hialino, tamanho e formato variiáveis (Cp). O citoplasma nestas células é periférico, o vacúolo central proeminente, o núcleo pode ser mais ou menos grande e os cloroplastos são raros. As células próximas à câmara larval constituem a medula (M) (Figs. 6 e 8) e nestas não sé observa acúmulo de substâncias fenólicas, mostrando-se então mais claras. As células medulares tendem a uma assumir uma disposição radiada ao redor da câmara larval. 'Dentro do canal de oviposição, na região acima e ao lado do teto da câmara larval, podem ser observadas projeções em formação (Prm) (Fig. 11). Estas apresentam células pequenas, citoplasma denso e núcleo proeminente, que são características de células meristemáticas. Essas projeções dão origem posteriormente a projeções parenquimáticas $(\operatorname{PrP})$, que deslocam as anteriormente formadas, transformando-se em espinhos mais tarde.

Os feixes vasculares pré-existentes (Fig. 12) modificam-se acentuadamente. Ocorre hiperplasia do parênquima (P) entre xilema $(\mathrm{Xi})$ e floema $(\mathrm{Fl})$. Tais células têm paredes finas, citoplasma hialino e tamanhos variados. As fibras $(\mathrm{Fb})$ estão presentes unicamente junto ao floema e algumas têm lume maior, enquanto outras, diminuto. Células parenquimáticas corticais também podem se diferenciar, formando novos elementos vasculares, mas nestes feixes neoformados, não se observa a presença de fibras.

A câmara larval (Figs. 6 e 8), situada na região central da galha, permanece inalterada em relação ao estádio anterior. As esclereídes (Es) (Fig. 13) têm o lume preenchido por protoplasma e as paredes contém vários canais de pontoação. Nelas não se observam cristais de oxalato de cálcio, mas estes podem estão presentes em algumas células parenquimáticas da medula.

Estádio 3 - As galhas neste estádio apresentam-se mais altas e largas, assumindo um formato globóide (Figs. 1d, $1^{\text {" }}$ fase e $2^{\mathrm{a}}$ fase). Os espinhos distribuem-se desigualmente, faltando na região basal e formando um tufo congesto na região apical. Tais espinhos são mais longos que os das outras partes da galha. 


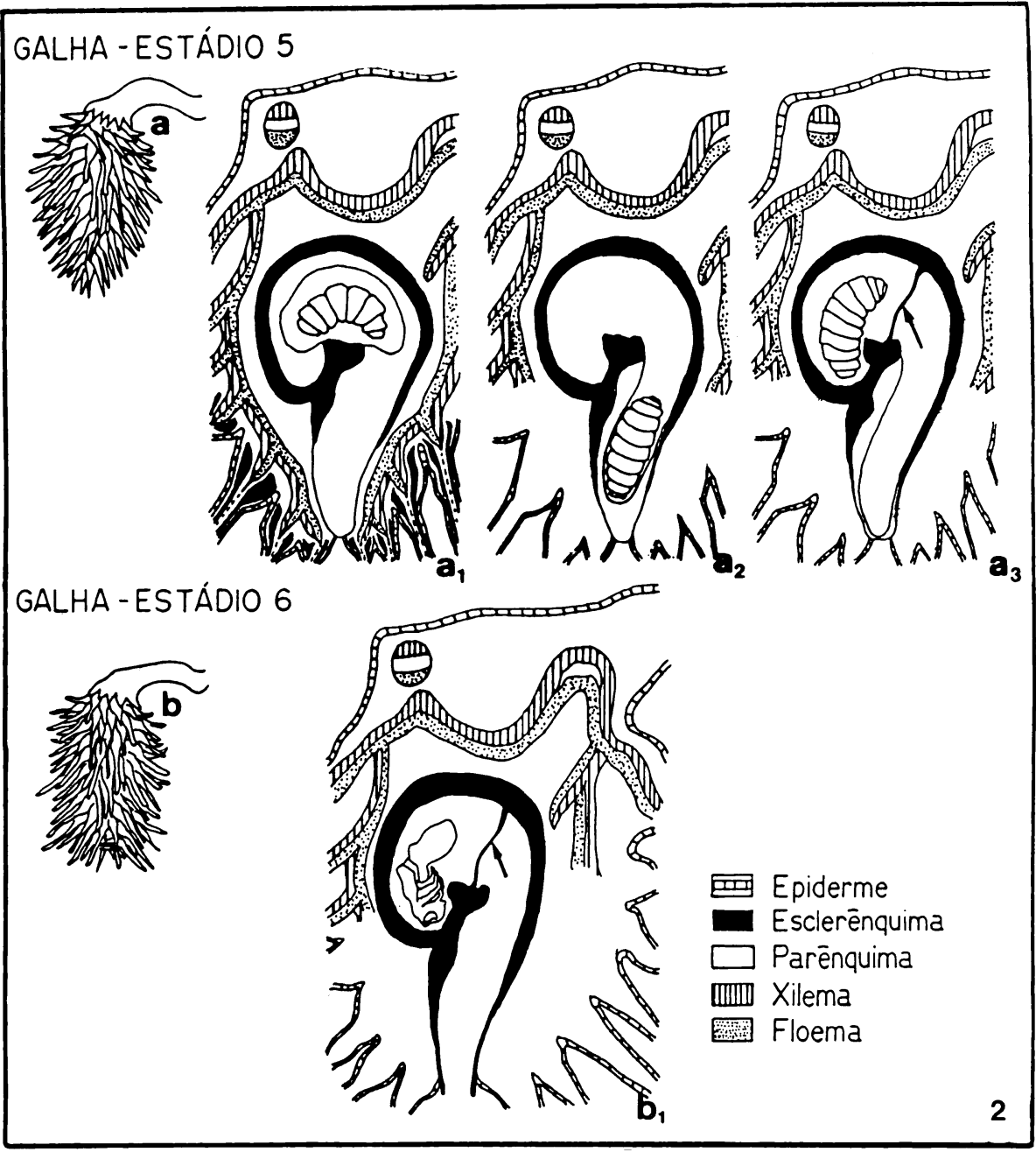

Fig. 2 - Piptadenia gonoacuntha. Diagrama representando o desenvolvimento das galhas. Estádios 5 e 6. mostrando aspectos externos à esquerda (a e b) e aspectos internos à direta (al, a2, a3 e b1). A seta indica o tabique de seda secretado pela larva.

Fig. 2 - Piptadenia gonoacuntha. Diagram featuring of the gall development. Stages 5 and 6, showing morphological aspects at left ( $a$ and $b)$ and anatomical ones at right ( $a 1, a 2, a 3$ and $b 1)$. The arrow show the silk pelicle produced by the larva.

Em corte também se distingue uma fase jovem (Figs. 1dl e 14), onde se observa um aumento generalizado do parênquima cortical. Na fase avançada (Figs. Id2 e 15) o parênquima medular aumenta muito e parte das esclereídes que envolvem a câmara larval desintegra-se. O aumento do parênquima contribui para aumentar o tamanho da galha. 
O córtex é percorrido por feixes vasculares modificados, que se conectam com os neoformados. As células parenquimáticas corticais apresentam as mesmas características anteriores, ou seja, vacúolo amplo e freqüentemente preenchido com substâncias fenólicas, que serão mantidas durante todo o desenvolvimento da galha. Na região entre o córtex e a medula, ou seja, região de transição (RTr)(Fig. 16) observam-se células com o vacúolo preenchido por substâncias fenólicas, mas de tamanho igual ao das medulares. Estas últimas encontram-se dispostas radialmente em relação à câmara larval e reconhecem-se duas regiões. A mais externa com células de conteúdo hialino (Ch) e paredes finas e a mais interna com células menores e citoplasma mais denso, freqüentemente com cristais romboédricos no vacúolo $(\mathrm{CCr})$. A câmara larval apresenta-se revestida por duas camadas de esclereídes.

As projeções parenquimáticas continuam a ser produzidas na região acima do teto da câmara larval e as situadas mais perifericamente começam a se diferenciar em espinhos (Ep)(Figs. 14 e 15). Aqueles ainda em formação são curtos e geralmente apresentam o ápice curvado. Os espinhos diferenciados vistos em corte transversal (Fig. 17) apresentam na epiderme (E) células salientes e, freqüentemente, tricomas tectores. O córtex mostra duas ou mais camadas, dependendo da altura em que passou o corte. Existe um abundante esclerênquima ocupando a região central e o feixe vascular é reduzido. O esclerênquima consiste de fibras $(\mathrm{Fb})$ que permanecem vivas na maturidade. Num feixe em fase final de diferenciação visto em corte longitudinal (Fig.

Figs. 3-5 - Piptadenia gonoacantha. Aspectos anatômicos do foliólulo sadio e do afetado com galha. Figs. 3-4. Foliólulo sadio. Fig. 5. Galha em estádio 1. Fig. 3. Corte transversal mostrando epiderme adaxial, parênquima paliçádico, parênquima esponjoso e nervura principal. Notar nesta o reforço de fibras e os elementos condutores entremeados por células parenquimáticas. Fig. 4. Aspectos das fibras com poucos canais de pontoações (setas) e das esclereídes contendo cristais de oxalato de cálcio. A parte mais escura das paredes das esclereídes está lignificada e a parte clara ainda não se lignificou. Fig. 5. A região da galha inclui a câmara larval com o indutor revestida por esclereídes, cuja parte mais espessa corresponde ao teto. Sobre este situam-se as projeções parenquimáticas e entre elas está o canal de oviposição. Ao redor da câmara larval encontram-se células parenquimáticas isodiamétricas. A região periférica à galha abrange o conjunto de células do mesofilo divididas ou alongadas, com ausência de espaços intercelulares. B - bainha; $\mathrm{Ca}$ - câmara larval; $\mathrm{CnO}$ - canal de oviposição; $\mathrm{Cr}$ - cristal; $\mathrm{Eb}$ - epiderme abaxial; Ed - epiderme adaxial; Es - esclereídes; $\mathrm{Fb}$ - fibras; I - indutor; $\mathrm{N}$ - nervura principal; $\mathrm{PE}$ - parênquima esponjoso; $\mathrm{PP}$ - parênquima paliçádico; PrP - projeção parenquimática; Te - teto da câmara larval.

Figs. 3-5 - Piptadenia gonoacantha. Anatomical aspects of non-affected and affected leaflets. Figs. 3-4. Non-affected leaflet. Fig. 5. Gall at stage 1. Fig. 3. Cross-section of the leaflet showing adaxial epidermis, palisade parenchyma, spongy parenchyma, and midrid. Observe the fibers surrounding the vascular elements and the parenchyma cells mixed with the latter ones. Fig. 4. Fibers with few pit channels (arrows) and sclereids with calcium oxalate crystals. Note in the sclereids the lignified dark wall and the non-lignified light wall. Fig. 5. The gall portion includes the larval chamber surrounded by sclereids; the enlarged region of sclereids corresponds to the roof of the chamber: Above the roof parenchymatic projections are present and among them there is the oviposition channel. Isodiametric parenchyma cells are observed near the larval chamber. Close to the gall, there are just divided or elongated chlorenchyma cells and no intercelular space among them. $\mathrm{B}$ - sheath; $\mathrm{Ca}$ - larval chamber; $\mathrm{CnO}$ - oviposition channel; $\mathrm{Cr}$ - crystal; $\mathrm{Eb}$ - abaxial epidermis: Ed - adaxial epidermis; Es - sclereids; fb - fibers; I - inducer; N - midrib; PE - spongy parenchyma; PP palisade parenchyma; PrP - parenchymatic projection, Te - larval chamber roof. 

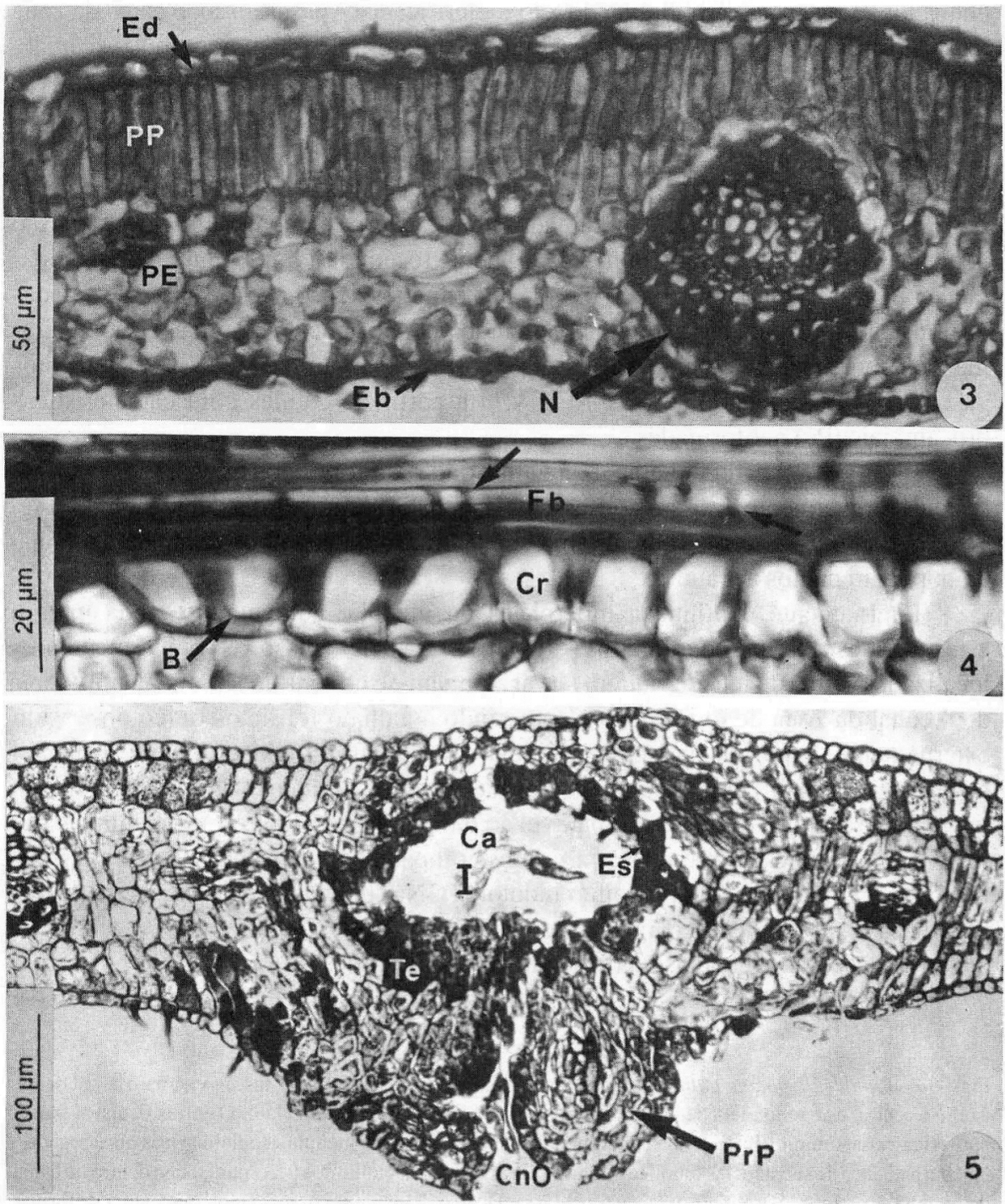

17), nota-se que as células epidérmicas e corticais são alongadas e preenchidas por substâncias fenólicas. Os elementos condutores do xilema (ElV) são longos e as paredes apresentam reforços anelados ou helicoidais. Não se observa a presença de bainha neste feixe.

Na galha em estádio 3 avançado (Fig. 15), ocorre desintegração de parte das esclereídes que envolvem a câmara larval, mas em contrapartida, há um aumento considerável no teto desta (Fig. 19). Além disso, ocorre intensa hiperplasia na medula, 
chegando esta a avançar por cima do teto esclerificado. Apesar disso, o canal da zona de oviposição ainda permanece. As células medulares que ficam por cima da câmara larval continuam a formar novos espinhos.

Observando-se a câmara larval (Fig. 19), constata-se que além do revestimento de esclereídes tornar-se bastante frouxo, as células medulares que entram em contato com o indutor apresentam frequientemente citoplasma denso, constituindo o tecido nutritivo (TN). As células das camadas mais externas da medula (Fig. 20) são pequenas e muitas delas mostram-se claramente recém divididas. Entretanto, comparado com as do tecido nutritivo, o citoplasma é menos denso. As células das camadas de transição apresentam o vacúolo preenchido por substâncias fenólicas e são ligeiramente menores que as células corticais. No córtex observam-se feixes com elementos vasculares diferenciando-se (EIV)(Fig. 2I) a partir de células com características procambiais $(\mathrm{Pc})$ neoformadas.

Estágio 4-A região apical da galha, onde são formados os espinhos, alongase consideravelmente e, como conseqüência, a galha assume um formato cônico (Fig. 1e). Ainda pode ser observada alguma concentração de espinhos no ápice da galha, embora bem menos acentuada.

Internamente continua a hiperplasia da medula, aumentando ainda mais a espessura desta nas porções laterais (Figs. 1e l e 22). Além disso, as células medulares localizadas acima do teto da câmara larval alongam-se no sentido anticlinal, obliterando o canal da zona de oviposição e conferindo à galha o formato cônico observado externamente. A maioria das células medulares apresenta citoplasma hialino. O tecido nutritivo apresenta células com citoplasma consideravelmente denso (Fig. 23). O tamanho da maioria destas é comparável ao das células medulares, mas algumas são muito menores e estão reunidas em grupos compactos, localizando-se preferencialmente nas regiões em contato com o indutor (I). Nas células corticais observam-se a presença de amiloplastos (Fig. 24, seta), que nos cortes mostram-se incolores. A quantidade dessas organelas tende a aumentar a partir deste estádio.

Estádio 5 - Os espinhos distribuem-se de maneira uniforme, não mais se

Figs. 6-8 - Piptadenia gonoacantha. Galha em estádio 2. Fig. 6. Fase jovem ( ${ }^{\text {a }}$ fase). A câmara larval ocupa a região central e ao redor dela a região medular mostra células de conteúdo claro. O córtex ocupa as partes periféricas, constituindo-se de células ligeiramente maiores que as da medula, isodiamétricas ou alongadas. Notar a presença de substâncias fenólicas (mais escuras). Fig. 7. Detalhe dos tricomas (setas) dentro do canal de oviposição. Fig. 8. Fase mais avançada ( $2^{a}$ fase). Dentro do canal de oviposição começam a se formar novas projeções parenquimáticas a partir das células medulares situadas acima do teto da câmara larval. Ca - câmara larval; $\mathrm{Co}$ - córtex; $\mathrm{CnO}$ - canal de oviposição; M - medula; PrP - projeção parenquimática, Te teto da câmara larval. Figuras 6 e 8 na ṃesma escala.

Figs. 6-8 - Piptadenia gonoacantha. Gall at stage 2. Fig. 6. Young phase (I st phase). The larval chamber is located in the center of the gall. Medullar light-content cells are close to it. In the periphery, cortical cells are present. They are larger, isodiametric and elongated than medullar cells. Observe the dark phenolic compounds. Fig. 7. Detail of the trichomes (arrows) in the ovipositon channel. Fig. 8. Advanced phase (2nd phase). In the oviposition channel, new parenchymatic projections are formed from medullar cells situated above the larval chamber roof. $\mathrm{Ca}$ - larval chamber; $\mathrm{Co}$ - cortex; $\mathrm{CnO}$ - oviposition channel; $\mathrm{M}$ - medulla; PrP - parenchymatic projection; Te - larval chamber roof. Figures 6 and 8 are in the same scale. 

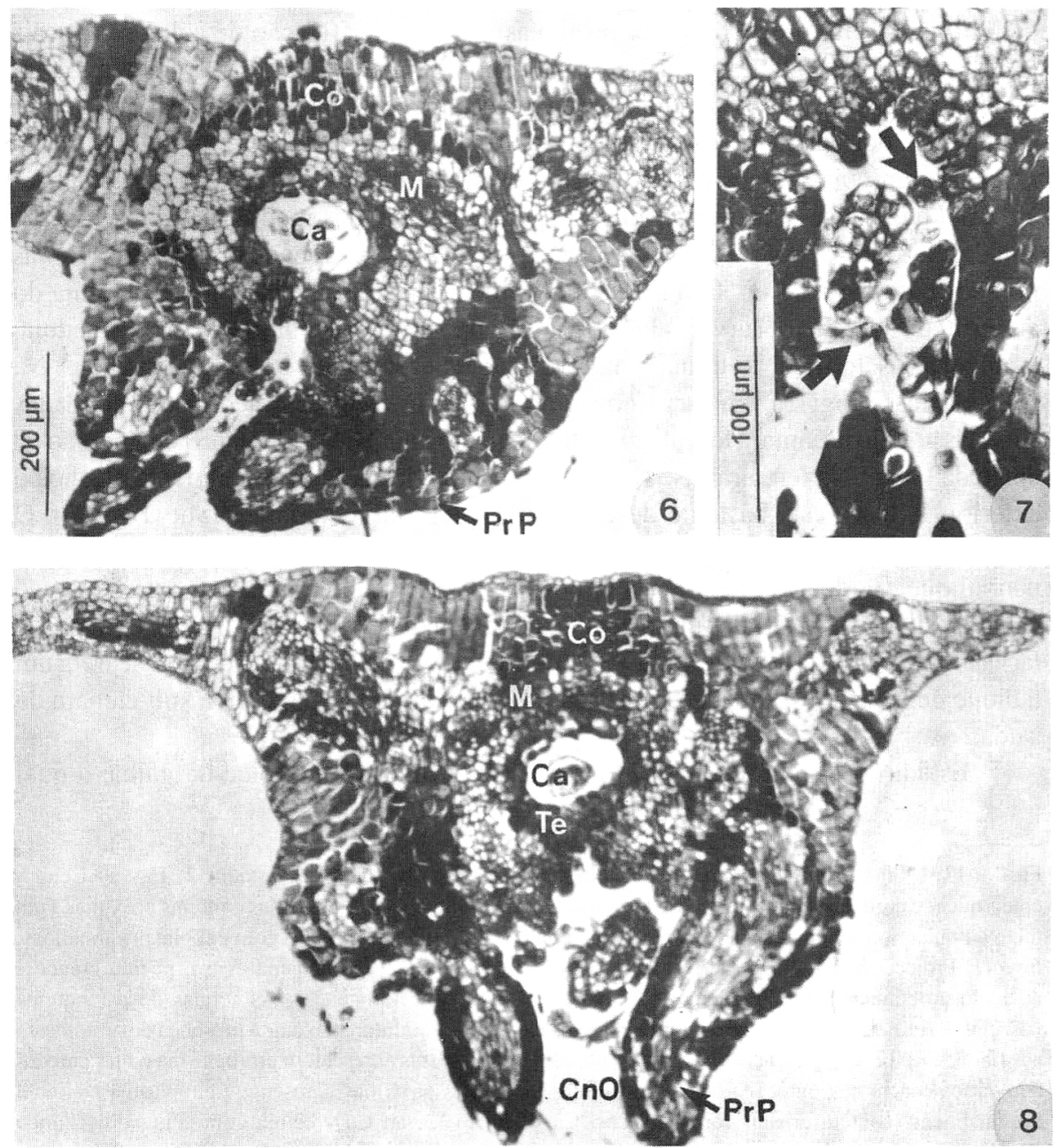

notando a concentração destes no ápice. Ao atingir este estádio, cessa o crescimento da galha (Fig. 2a). A extremidade distal do foliólulo até a região de junção com a galha é eliminada, enquanto que a região que une a galha à raque torna-se lateralmente mais estreita, porém mais espessa, formando então o pedúnculo da galha.

Em corte podem ser reconhecidas três fases. Na primeira, as mudanças mais importantes ocorrem na estrutura da câmara larval (Figs. 2a1 e 25). Não se observa mais a presença de tecido nutritivo, mas a larva desenvolve-se bastante e passa a consumir as células da medula, aumentando o tamanho da câmara larval. Concomitantemente, as células situadas na zona de transição entre córtex e medula esclerificam-se, resultando na formação de 4 ou 5 camadas de esclereídes pequenas (Fig. 
27), com paredes bastante espessas, percorridas por numerosos canais de pontoação e com lume estreito preenchido por protoplasma. A esclerificação de células corticais resulta na formação de esclereídes de tamanho maior, com lumes amplos e freqüentemente preenchidos por substâncias fenólicas e paredes mais finas, que também são percorridas por canais de pontoação. Entre esses dois tipos, ocorrem células esclerificadas, em cujos lumes observam-se a presença de cristais de oxalato de cálcio. No final desta fase, a larva consome o restante das células medulares, alcançando a zona esclerificada. Assim, a câmara larval fica revestida apenas por esclereídes nas porções basais e laterais. Parte das células medulares alongadas, situadas acima do antigo teto da câmara larval, além daquelas na região de transição córtex-medula, também se esclerifica, resultando na formação de esclereídes bastante alongadas. $\mathrm{Na}$ segunda fase (Fig. 2a2) a larva consome também as células medulares alongadas situadas acima da câmara larval, abrindo assim um canal de saída $(\mathrm{CnS})$ em direção ao ápice da galha. Na terceira fase (Fig. 2a3), o canal de saída eventualmente alcança o exterior. A larva está bastante desenvolvida e retorna à câmara larval (Fig. 26). O antigo teto e as células medulares acima dele, que são esclerificados, formam um septo parcial que divide a câmara larval em duas sub-câmaras. Uma destas está ligada ao canal de saída e a outra, de fundo cego, é chamada de sub-câmara pupal (sCp), pois a larva aloja-se nela no fim desta fase. Depois de ter-se instalado ali, a larva secreta um tabique de seda que veda a comunicação da sub-câmara pupal com a sub-câmara de saída.

Estádio 6 - Neste estádio forma-se uma abertura no ápice da galha, a qual

Figs. 9-13 - Piptadenia gonoacantha. Detalhes dos tecidos da galha em estádio 2. Fig. 9. Células epidérmicas e corticais adjacentes contendo substâncias fenólicas. Fig. 10. Células corticais próximas a um feixe vascular apresentam citoplasma periférico com vacúolo grande, e outras com citoplasma granuloso. Fig. 11. Projeção meristemática. As características das células são citoplasma denso, núcleo grande e nucléolo proeminente. Fig. 12. Feixe vascular alterado pela cecidiogênese. As células do parênquima vascular dividiram-se e se diferenciaram em novos elementos condutores. Notar a presença de protoplasto nas fibras. Fig. 13. Câmara larval circundada por esclereídes. Estas apresentam protoplasma e suas paredes têm vários canais de pontoação (seta). As células medulares próximas apresentam citoplasma hialino e eventualmente contém cristais romboédricos. Ca - câmara larval; $\mathrm{Cg}$ - célula com conteúdo fenólico granuloso; Cho - célula com conteúdo fenólico homogêneo; $\mathrm{Cp}$ - célula com citoplasma periférico; $\mathrm{Cr}$ cristal; Ed - epiderme adaxial; Es - esclereídes; Fb - fibra; Fl - floema; FV - feixe vascular; I - indutor; P parênquima; Prm - projeção meristemática; Xi - xilema. Figuras na mesma escala.

Figs. 9-13 - Piptadenia gonoacantha. Details of gall tissues at stage 2. Fig. 9. Epidermal, and cortical cells next to each other containing phenolic compounds. Fig. 10. Cortical cells near to a vascular bundle present peripheric citoplasm, a large vacuole, while the other ones present granular citoplasm. Fig. 11. Meristematic projection. The characteristics of the cells are dense citoplasm, large nucleus and conspicous nucleolus. Fig. 12. Gall modified vascular bundle. The vascular parenchyma cells divided and formed new vascular elements. Note the presence of protoplasm in the fibers. Fig. 13. Larval chamber surrounded by sclereids. These cells present protoplasm and many pit channels (arrow) in the wall. The medullar cells near the sclereids present hyalinous citoplasm, while rhombic crystals may also occur. $\mathrm{Ca}$ - larval chamber; $\mathrm{Cg}$ - cell with granular phenolic content; Cho - cell with homogeneous phenolic content; $\mathrm{Cp}$ - cell with peripheric citoplasm; $\mathrm{Cr}$ - crystal; Ed - adaxial epidermis; Es - sclereids; Fb - fiber; Fl - phloem; FV - vascular bundle; $\mathrm{I}$ - inducer; P - parenchyma; Prm - meristematic projection; Xi - xylem. Figures in the same scale. 

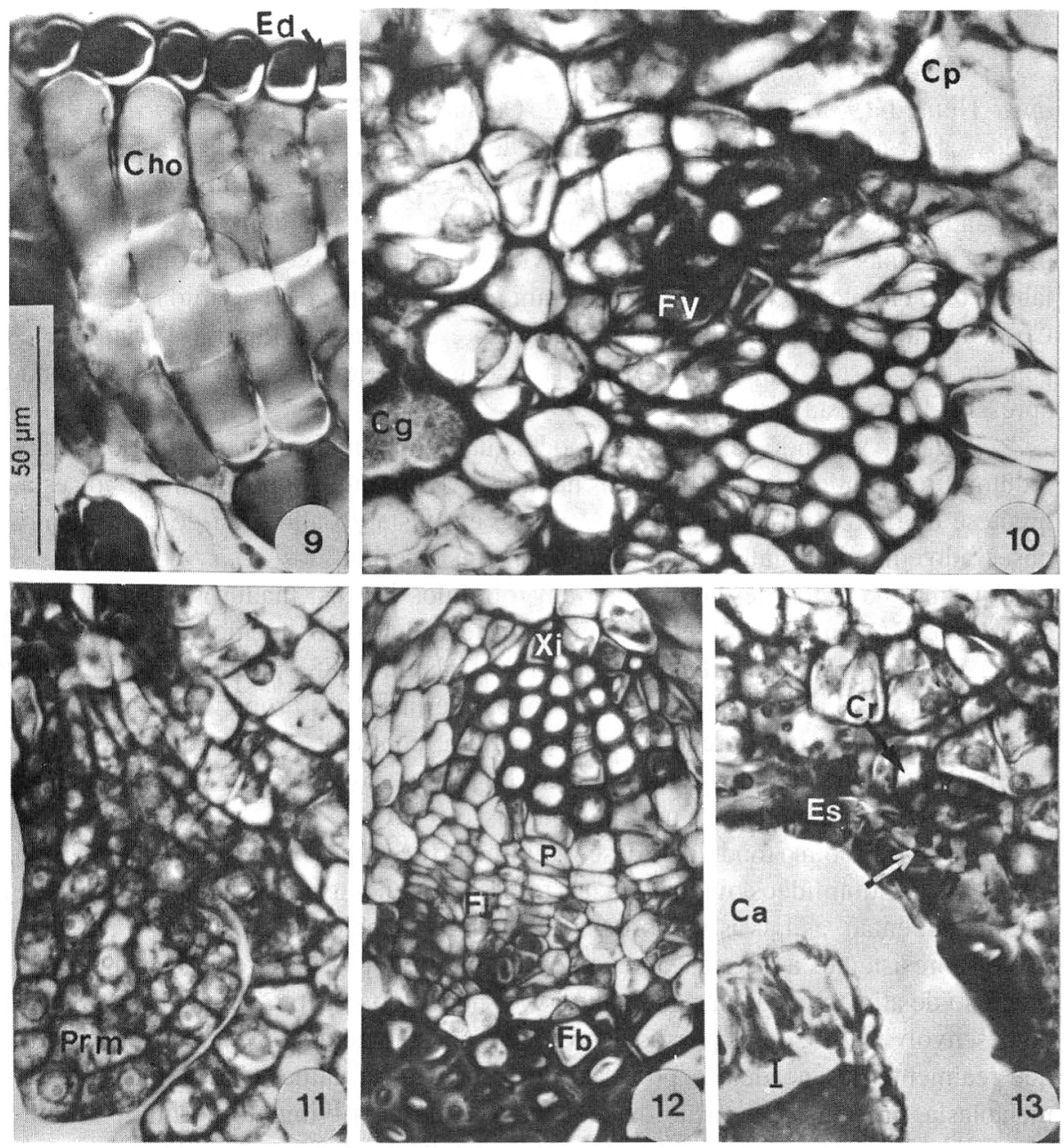

alarga-se posteriormente (Fig. 2b). A galha, quando entra em senescência, tende a perder a cor original e a assumir uma cor acastanhada, aparentando estar seca.

Em corte observa-se que a formação da abertura apical ocorre por degradação das poucas células medulares situadas no ápice da galha e que não foram consumidas pela larva do inseto (Figs. 2 b 1 e 28). Completa-se assim a formação do canal de saída. Não se observa mais a presença de medula (Fig. 28) e assim o tecido parenquimático da galha constitui-se apenas de células corticais. O inseto (I) observado na sub-câmara pupal entra em fase de pupa. 


\section{DISCUSSÃO}

No gênero Piptadenia foram observadas várias gallhas (e. g., Rübsaamen 1907 apud Houard 1933, Tavares 1920, 1922, Occhioni 1979, Fernandes et al. 1988). Todos esses autores relatam a existência de uma galha idêntica à descrita neste trabalho e referem-se ao indutor como sendo um cecidomiídeo. Arduin et al. (1994), estudando este mesmo material, encontraram larvas de cecidomí́deos em galhas dissecadas, mas de galhas bem desenvolvidas, coletadas no campo e mantidas em laboratório em placas de Petri, só obtiveram insetos adultos de Torymidae. Segundo Costa Lima (1962) a grande maioria dos representantes da família Torymidae é parasita de galhas. Arduin et al. (1994) discutem o elevado grau de parasitismo apresentado por esta galha.

A galha, segundo Mani (1964), pode atuar como uma adaptação de defesa do indutor, protegendo-o contra inimigos naturais. Alguns autores põem em dúvida esta hipótese de proteção (e.g., Price et al. 1987) em vista do alto grau de parasitismo observado em muitas galhas, inclusive nesta aqui descrita.

O fato da galha desenvolver-se em foliólulos jovens, maduros e até mesmo senescentes (Arduin et al. 1994) é uma indicação de que os tecidos foliares dessa planta mantém sua competência (Church \& Galston 1988) por toda a sua vida. Rohfritsch (1992) afirma que os tecidos jovens seriam mais propícios para reagir à indução do que os já diferenciados. Esta autora, contudo, salienta que é errôneo generalizar de que só tecidos meristemáticos ou jovens são capazes de reagir ao ataque de cecidozoários. Esta galha é um exemplo disso.

De acordo com o modelo de desenvolvimento de galhas proposto por Rohfritsch (1992), os cecidomiídeos ovipositam nas folhas diretamente no local onde se formará a galha ou, então, as larvas vão procurá-los depois da eclosão. Neste caso, elas são móveis e resistentes à dessecação e, ao encontrarem um local apropriado, iniciam o processo de alimentação, causando alterações no tecido vegetal. Esta primeira etapa do desenvolvimento, cujos passos ocorrem em questão de horas, é a mais crítica e a que realmente desencadeia o processo de formação da galha. Caracteriza-se pela metaplasia, ou seja, a alteração da seqüência de desenvolvimento normal para um novo padrão de crescimento. A segunda etapa também é rápida e caracteriza-se pela hiperplasia, formando-se então novos tecidos pela divisão celular. Na terceira etapa, os tecidos cecidiogênicos aumentam e começam a se diferenciar e finalmente na quarta etapa a galha pára de crescer e a diferenciação dos tecidos se completa. No caso da galha aqui descrita, a oviposição ainda não pôde ser observada e, conseqüentemente, a primeira etapa do desenvolvimento da galha também não o foi. As demais etapas do desenvolvimento desta galha seguem o modelo proposto por Rohfritsch (1992).

Não se sabe ainda como é o processo de alimentação do indutor na galha de $P$. gonoacantha. $\mathrm{O}$ fato de a câmara larval estar revestida por esclereídes nos primeiros estádios de desenvolvimento, sugere que a larva estaria nutrindo-se das reservas do vitelo. É possível, também, em vista dos numerosos canais de pontoação e da presença 


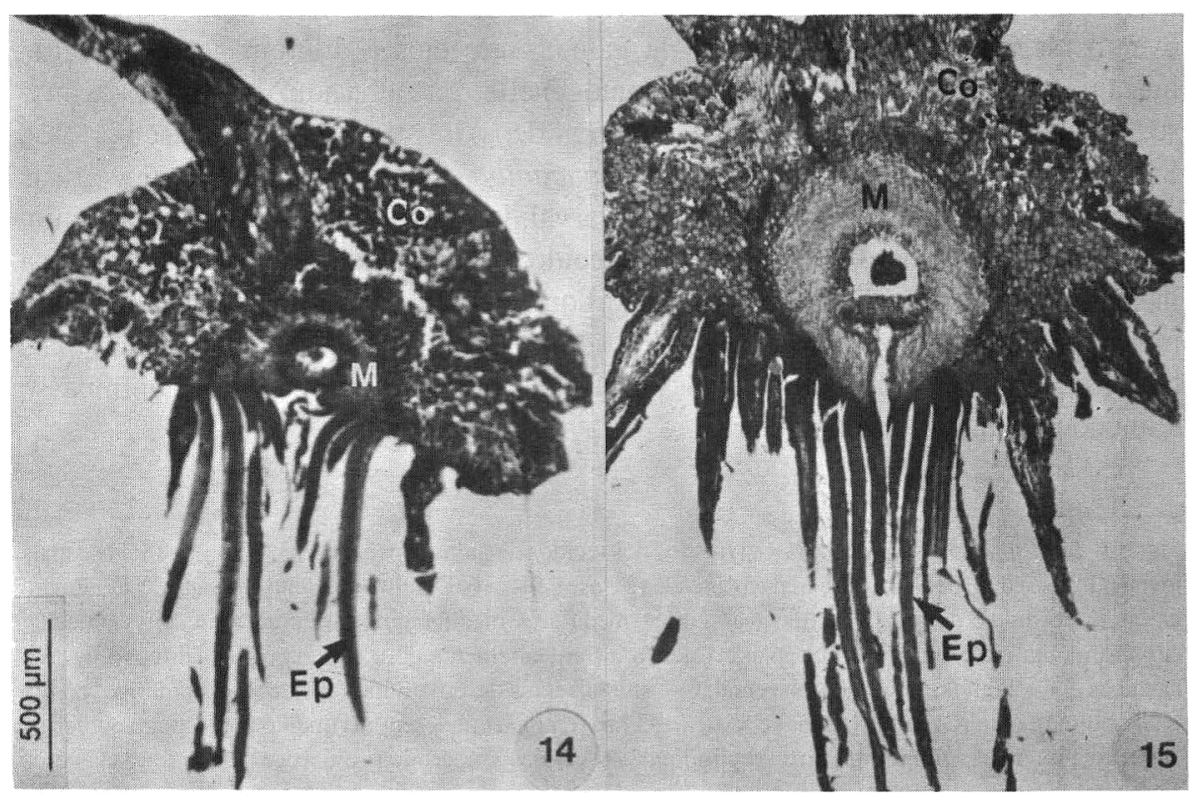

Figs. 14-15-Piptadenia gonoacantha. Galha em estádio 3. Fig. 14. Fase mais jovem ( ${ }^{2}$ fase). Nesta ocorre maior desenvolvimento do tecido cortical, comparado com o da medula. Fig. 15. Fase mais avançada ( $2^{a}$ fase). O crescimento do córtex foi menor e a medula se desenvolveu mais. Co - córtex; Ep - espinho; M medula. Figuras na mesma escala.

Figs. 14-15-Piptadenia gonoacantha. Gall at stage 3. Fig. 14. Young phase (1st phase). The cortical tissue shows increased when compared with less developed medullar tissue. Fig. 15. Advanced phase (2nd phase). The cortex shows a minor enlargement, while the medulla is larger than it. Co - cortex; Ep - thorn; M medulla. Figures are in the same scale.

de protoplasma nessas células, que este tecido mecânico atuasse como um tecido de transferência de nutrientes para o inseto e/ou de compostos produzidos por ele, que estariam envolvidos no desenvolvimento cecidiogênico. A instalação do tecido nutritivo na segunda fase do estádio 3 sugere que o indutor, em fase larval, estaria alimentando-se desse tecido e crescendo ativamente. No estádio 5 , a presença do tecido nutritivo não é mais observada, mas o aumento da câmara larval e a formação do canal de saída é um claro indício de que o indutor consome as células medulares. Rohfritsch (1992) sugere que nessas condições a larva rasparia as células com a espátula, ingerindo os fragmentos.

Segundo Rohfritsch (1980) as células dos tecidos nutritivos são formadas geralmente a partir de células parenquimáticas próximas dos locais de atividade alimentar do indutor e não apenas desempenham um papel-chave na nutrição da larva, como também são importantes no desenvolvimento e fisiologia da galha, desde que a larva mantenha-se viva. Tal afirmação é respaldada pelo fato de que se a larva for 
morta por qualquer motivo, as características das células nutritivas desaparecem e os eventos seguintes na morfogênese da galha, entre eles a diferenciação do tecido mecânico, cessam. O desenvolvimento ontogenético da galha aqui descrita aproximase do modelo galha de cobertura (de cecidomiídeos) mostrado por Rohfritsch (1992). Salienta-se apenas que na galha de $P$. gonoacantha existe um tecido mecânico mais restrito, revestindo as paredes da câmara larval, logo no ínicio do desenvolvimento, enquanto que no modelo de Rohfritsch o tecido mecânico aparece mais tarde, após a instalação do tecido nutritivo. $\mathrm{Na}$ galha aqui descrita, a formação de um tecido mecânico muito mais amplo, semelhante ao modelo de Rohfritsch, ocorre bem mais tarde, quando o tecido nutritivo não está mais presente, mas a larva continua se alimentando das células medulares.

Figs. 16-21 - Piptadenia gonoacantha. Aspectos dos tecidos de galhas em estádio 3. Figs. 16-18. Fase mais jovem ( $1^{a}$ fase). Figs. 19-21. Fase mais avançada ( $2^{a}$ fase). Fig. 16. Detalhe (de dentro para fora) da câmara larval, da medula e da região de transição córtex-medula. A medula apresenta uma zona com células de citoplasma hialino e outra com citoplasma denso e freqüentemente com cristais romboédricos. Fig. 17. Detalhes dos espinhos em corte transversal. Os espinhos mais desenvolvidos apresentam epiderme, córtex (parênquima), esclerênquima (fibras) e feixe vascular; os ainda em desenvolvimento apresentam epiderme e córtex. Fig. 18. Espinho em corte longitudinal. As células epidérmicas e corticais são alongadas e os elementos vasculares apresentam reforços anelares. Neste espinho as fibras ainda não se lignificaram. Fig. 19. Detalhe da câmara larval. Notar o aumento de tamanho do teto da câmara larval e concomitante redução das esclereídes na parede da câmara. O tecido medular avança por sobre o teto da câmara, tendendo a recobrilo. Fig. 20. Aspecto das células medulares e corticais; as mais próximas da câmara larval constituem o tecido nutritivo, as demais apresentam o citoplasma relativamente denso. As células corticais têm o vacúolo preenchido com substâncias fenólicas. Fig. 21. Detalhe de um feixe vascular em diferenciação, mostrando as células procambiais e os elementos vasculares ainda com protoplasma e as paredes com reforços anelares. Ca - câmara larval; Co - córtex; CCr - célula com cristal; $\mathrm{Ch}$ - célula com citoplasma hialino; E - epiderme; EIV - elemento vascular; Fb - fibra; FV - feixe vascular; I - indutor; M - medula; P - parênquima; Pc procâmbio; RTr - região de transição; Te - teto da câmara larval; TN - tecido nutritivo. Figuras 16 e 17 na mesma escala; figuras 19 e 20 idem.

Figs - 16-21 - Piptadenia gonoacuntha. Aspects of gall tissues at stage 3. Figs. 16-18. Young phase (1st phase). Figs. 19-21. Advanced phase (2nd phase). Fig. 16. Detail (from inside to outside) of the larval chamber, medulla and transitional region of the medulla-cortex. The medulla shows a zone with hyalinous citoplasm cells and another one with densely citoplasmatic cells containing rhombic crystals. Fig. 17. Details of thorns in cross-section. The more developed thorns present epidermis, cortex (parenchyma), sclerenchyma (fibers), and vascular bundle; the less developed thorns present epidermis, and cortex, while other structures are still forming. Fig. 18. Thorn in longitudinal section. The epidermal and cortical cells are elongated and the tracheal elements present annular reiforcement. Fibers walls are not lignified at this stage. Fig. 19. Detail of the larval chamber. Note the increased size of the chamber roof and the simultaneous decrease in the sclereids number arround the wall chamber. The medullar tissue increace above the roof, almost involving it. Fig. 20. Aspects of the medullar and cortical cells: the medullar cells near the larval chamber constitute the nutritive tissue and the remaining ones present a relatively dense citoplasm. The cortical cells present the vacuole filled by the phenolic compounds. Fig. 21. Detail of a vascular bundle at differentiation, showing procambial cells and vascular elements with protoplasm and annular wall reiforcement. Ca - larval chamber; $\mathrm{CCr}$ - cell with crystal; $\mathrm{Ch}$ - cell with hyalinous citoplasm; $\mathrm{Co}$ - cortex; E- epidermis; ElV - vascular element; Fb - fiber; I - inducer; $\mathrm{M}$ - medulla; $\mathrm{P}$ - parenchyma; $\mathrm{Pc}$ - procambium; $\mathrm{RTr}$ - transitional region; Te - roof of the larval chamber; TN - nutritive tissue. Figures 16 and 17 in the same scale; figures 19 and 20 too. 

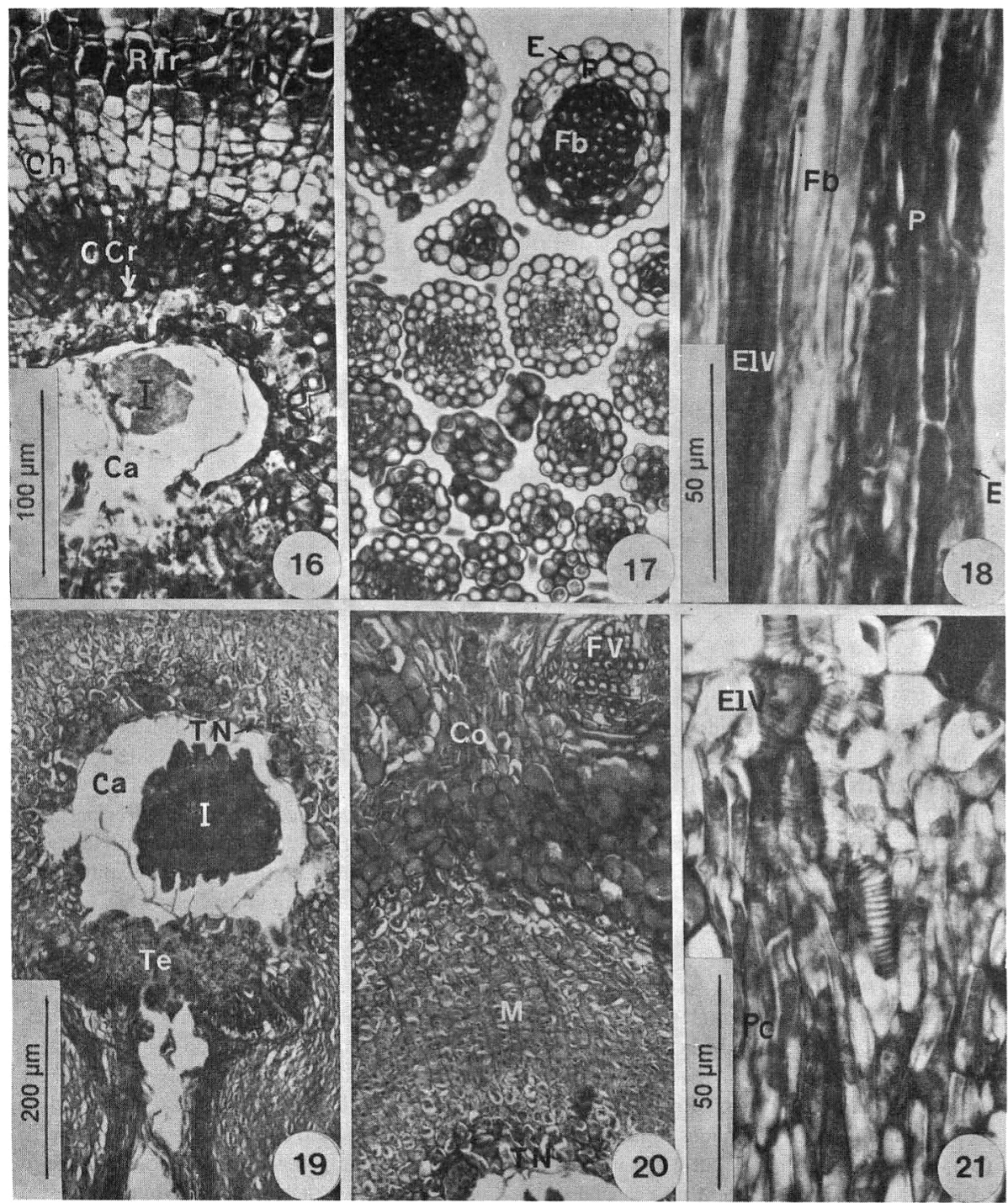

$\mathrm{Na}$ galha madura encontram-se tanto estruturas cujos tecidos assemelham-se aos dos foliólulos sadios, como outras que apreṡentam diferenças consideráveis. Os espinhos que envolvem a galha não são observados na folha, nem em quaisquer outras partes da planta. São, portanto, estruturas neoformadas, embora possuam alguns tecidos semelhantes aos observados no foliólulo sadio. A epiderme do espinho, por exemplo, apresenta tricomas tectores idênticos aos observados nos foliólulos; o sistema vascular é envolvido por fibras vivas e os elementos traqueais são longos e 

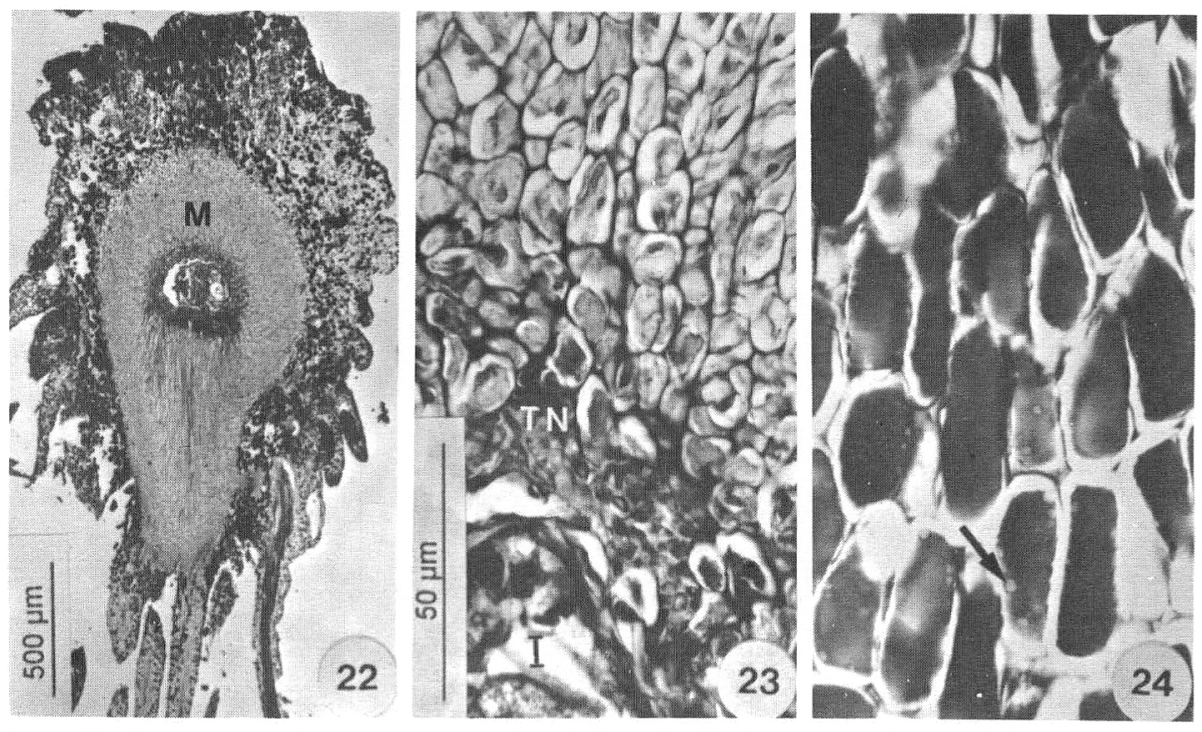

Figs. 22-24 - Piptadenia gonoacantha. Galha em estádio 4. Fig. 22. Aspecto geral. A medula mostra um grande desenvolvimento. As células acima do teto da câmara larval alongam-se no sentido longitudinal da galha. Fig. 23. Detalhe do tecido nutritivo. Suas células apresentam-se com citoplasma denso e tamanhos variados. Fig. 24. Detalhe das células corticais, onde podem ser observados amiloplastos (seta). I - indutor; M - medula; TN - tecido nutritivo. Figuras 23 e 24 na mesma escala.

Figs. 22-24 - Piptadenia gonoacantha. Gall at stage 4. Fig. 22. General aspect: the medullar region show a great development. Cells above the larval chamber roof are elongated. Fig. 23. Detail of the nutritive tissue. The densely citoplasmatic cells present different sizes. Fig. 24. Detail of cortical cells with amiloplasts (arrow). I - inducer; M - medulla; TN - nutritive tissue. Figures 22 and 23 are in the same scale.

Figs. 25-28 - Piptadenia gonoacantha. Figs. 25-27. Galhas em estádio 5. Fig. 28. Galha em estádio 6. Fig. 25. Aspecto geral da fase jovem ( $1^{\mathrm{a}}$ fase). Notar a esclerificação das células na zona de transição entre córtex e medula. Fig. 26. Aspecto geral da fase final ( $3^{\mathrm{a}}$ fase). O inseto retornou a esta, instalando-se na sub-câmara pupal. Fig. 27. Detalhe da região de transição córtex-medula. As esclereídes menores são de origem medular e as maiores de origem cortical. Entre esses dois tipos de esclereídes, há um tecido fibroso, junto ao qual ocorre uma camada de esclereídes pequenas com cristais. Fig. 28. O inseto em fase de pupa, encontra-se alojado na sub-câmara pupal, que é vedada por um tabique de seda (seta). Notar o canal de saída já aberto e a ausência de tecido medular. CnS - canal de saída; Co - córtex; $\mathrm{Cr}$ - cristal; I - inseto; M - medula; sCp - sub-câmara pupal.

Figs. 25-28 - Piptadenia gonoacantha. Figs. 25-27. Galls at stage 5. Fig. 28. Gall at stage 6. Fig. 25. General aspect of the young phase (1st phase). Note the sclerified zone between cortex and medulla. Fig. 26. General aspect of the last phase (3rd phase). The insect is in the pupal sub-chamber. Fig. 27. Detail of transitional region cortex-medulla. The small sclereids are originated from medullar cells and the large ones, from cortical cells. Between these sclerenchymatic layers above described, there is a fibrous tissue and a layer of small sclereids with crystals. Fig. 28. The insect at pupal phase is located in the pupal sub-chamber which it is closed by a silk pelicle (arrow). Note that the exit channel is already openned and that the medullar tissue has disappeared. CnS - exit channel; Co - cortex; Cr - crystal; I - insect; $\mathrm{M}$ - medulla; sCp - pupal subchamber. 


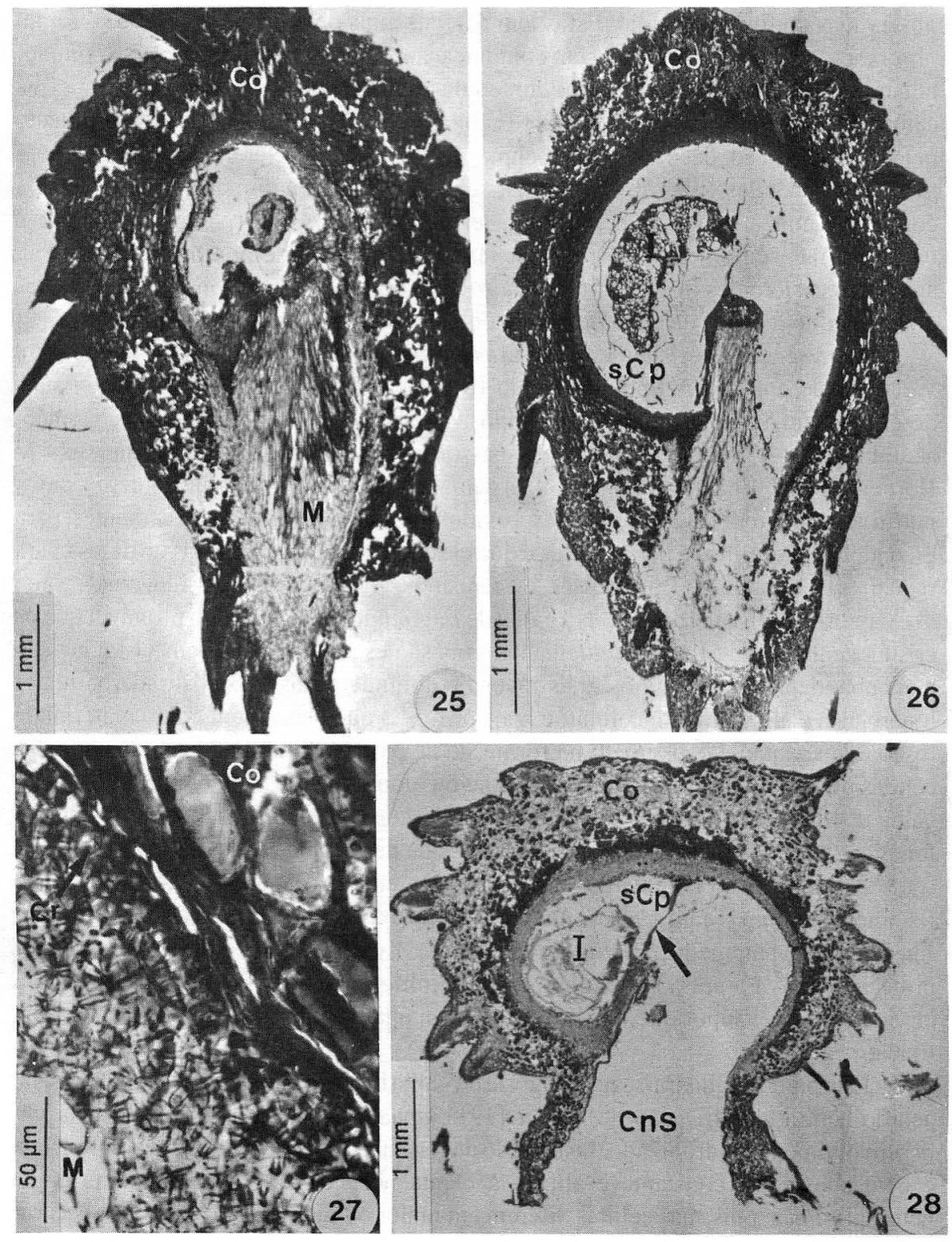


finos, com reforços anelados ou helicoidais, como observado nas nervuras normais, mas é desprovido de bainha esclerificada. As células do córtex do espinho, assim como as do corpo da galha, têm pouca semelhança com as células do clorênquima, pois são muito vacuoladas, preenchidas por substâncias fenólicas e desprovidas de cloroplastos.

As esclereídes que revestem a câmara larval diferem totalmente das esclereídes observadas no foliólulo sadio. Estas têm paredes mais ou menos espessas e só foram observados canais de pontoação em comunicação com fibras; o lume é quase completamente preenchido por um cristal cúbico ou romboédrico, envolvido por uma fina camada de protoplasma, sendo portanto células vivas. Tudo indica terem se originado pela esclerificação de células da bainha do feixe. As esclereídes cecidiogênicas também são células vivas, mas originam-se de células parenquimáticas medulares ou corticais e nunca estão associadas com feixes vasculares. A espessura da parede é variável, mas sempre é percorrida por numerosos canais de pontoação. Em geral, apenas as esclereídes que se formam na zona de transição córtex-medula e naquelas que constituem o teto da câmara larval contêm cristais de oxalato de cálcio.

A presença de cristais em tecidos cecidiogênicos é considerada mais rara e variável que em outros tipos de tecido (Meyer \& Maresquelle 1983). Os cristais desempenham diversas funções nos tecidos vegetais sadios, tais como balanço iônico, acúmulo de sais, apoio mecânico, dissuassor contra predadores, etc (Franceschi \& Horner 1980). Fernandes et al. (1989) argumentam que as galhas, que contêm tecidos nutritivos ricos em nutrientes e desprovidos de aleloquímicos, são atraentes para predadores, inquilinos e parasitóides e que elas podem ter mecanismos de defesa para reduzir esses ataques. Entre esses mecanismos, os cristais poderiam atuar como dissuassores contra herbivoria. Na galha de $P$. gonoacantha, é pouco provável que os cristais tenham uma função semelhante, pois são escassos. Tendo em vista que são mais abundantes nos estádios mais jovens e diminuem nos estádios onde há maior hiperplasia e alongamento celular, é mais provável que eles atuem como material de reserva, que então é consumido na formação de parede primária e lamela média das células que estão em processo de divisão e/ou alongamento. Salienta-se ainda que a galha de $P$. gonoacantha apresenta um tecido cortical amplo, rico em substâncias fenólicas que podem atuar como dissuassoras de herbivoria em lugar dos cristais.

A presença do tabique de seda vedando a entrada da sub-câmara pupal é um fenomeno comum (Mani 1964), citando-se como exemplo as observações de BoysenJensen (1948) para galha de Mikiola fagi em Fagus silvatica. Segundo esse autor, tal proteção evitava a entrada de umidade e a proliferação de fungos, que matariam a larva. É razoável supor que o tabique de seda na galha aqui descrita poderia ter uma função semelhante.

Esta galha enquadra-se na categoria de galha histióide do tipo prosoplásmica, de acordo com a classificação de Küster (1911 apud Mani 1964), pois apresenta um desenvolvimento padronizado, resultando na formação de uma estrutura característica e bem conspícua, constante e atípica à planta hospedeira. É também uma galha heteroplásmica, pois suas células diferem em maior ou menor grau daquelas observa- 
das no tecido não afetado. Pela presença de apenas uma câmara larval, que nesta gălha é ocupada por apenas uma larva, conclui-se também que ela é do tipo monotálamo. A presença de larvas de cecidomiídeos e as observações do seu desenvolvimento aproximam-na do modelo de galha de cobertura de cecidomiídeo proposto por Rohfritsch (1992).

\section{AGRADECIMENTOS}

Os autores agradecem ao Conselho Nacional de Desenvolvimento Científico e Tecnológico (CNPq), pelas bolsas concedidas (Proc. n. ${ }^{\circ}$ 830661/90-5 e 301776/83).

\section{REFERENCIAS}

ARDUIN, M. 1992. Estudo morfológico e ontogenérico de gallas foliares em jacaré - Piptadenia gonoacantha (Mart.) Macbr. (Fabales, Mimosaceae). Dissertação de Mestrado, Inst. Bioc. Univ. S. Paulo, São Paulo.

ARDUIN, M., KRAUS, J. E. \& VENTURELLI, M. 1991. Estudo morfológico de galha achatada em folha de Struthanthus vulgaris Mart. (Loranthaceae). Revta bras. Bot. 14: 147-156.

ARDUIN, M., KRAUS, J.E. \& MONTENEGRO, G. 1994. Morfologia e fenologia de galhas foliares de Piptadenia gonoacantha (Fabales, Mimosaceae). Revta bras. Entomol. 38: 79-89.

BISSING, D. R. 1974. Haupt's gelatin adhesive mixed with formalin for affixing paraffin sections to slides. Stain Techlnol. 49: 116-117.

BOYSEN-JENSEN, P. 1948. Formation of galls by Mikiola fagi. Physiol. Plant. I: 95-108.

CARLQUIST, S. 1982. The use of ethylenediamine in softening hard plant structures for paraffin sectioning. Stain Tecllnol. 57: 311-317.

CARROCINI, R. 1989. Aspectos ontogênicos, morfológicos e estruturais da gallha foliar de Phoebe brasiliensis Mez. (Lauraceue). Dissertação de Mestrado, Inst. Bioc. Univ. S. Paulo, São. Paulo.

CHAMBERLAIN, C. J. 1932. Methods in plant histology. The University of Chicago Press, Chicago.

CHURCH, D. L. \& GALSTON, A. W. 1988. Kinects of determination in the differentiation of the isolated mesophyll cells of Zinnia elegans to tracheary elements. Plant Physiol. 88: 92-96.

COSTA LIMA, A. 1962. Insetos do Brasil, tomo 12. Escola Nacional de Agronomia. Rio de Janeiro. p. 278-280.

FERNANDES, G. W. \& MARTINS, R. P. 1985. As galhas. Ciência Hoje 4: 59-64.

FERNANDES, G. W., TAMEIRÃO NETO, E. \& MARTINS, R. P. 1988. Ocorrência e caracterização de galhas entomógenas na vegetação do campus Pampulha da Universidade Federal de Minas Gerais. Rev. bras. Zool. 5: 11-19.

FERNANDES, G. W.,PRESZLER, R. W. \& GRIM, J. N. 1989. The occurrence of crystals in a cynipid leaf gall on Quercus turbinella. Beitr. Biol. Pflanzen 65: 377-383.

FRANCESCHI, V. R. \& HORNER, H. T. 1980. Calcium oxalate crystals in plants. Bot. Rev. 46: 361-427.

GARDNER, R. O. 1975. An overview of botanical clearing technique. Stain Teclinol. 30: 99-105.

HOUARD, C. 1933. Les zoocécidies des plantes de l'Amérique du Sud et de l'Amérique Centrale. Librairie Scientifique Hermann et Cie. Paris.

ISAIAS, R. M. S. 1992. Anatomia de follha e das gallhas foliares de Ficus noronhae Oliver. Dissertação de Mestrado, Museu Nacional da Univ. Fed. Rio de Janeiro. Rio de Janeiro.

JOHANSEN, D. A. 1940. Plant microtechinique. McGraw-Hill Book Co, New York.

KRAUS, J. E., MONTENEGRO, G. \& KIM, A. J. 1993. Morphological studies on entomogenous stem galls of Microgramma squamulosa (Kauf.) Sota (Polypodiaceae). Am. Fern J. 83: 120-128.

MANI, M. S. 1964. Ecology' of plant galls. Dr Junk Publisher. The Hague.

MEYER, J. \& MARESQUELLE, H. J. 1983. Anatomie des galles. Gebrïder Borntraeger. Berlin. 
NEVES, L. J. 1987. Morfologia. desenvolvimento e anatomia de Ficus tomentella Miq. (Moraceae). Tese de Doutorado, Inst. Bioc. Univ. de S. Paulo. São Paulo.

NORTHEN, H. T. 1936. Histological aplications of tannic acid and ferric chloride. Stuin Technol. 11: 2324.

OCCHIONI, P. 1979. "Galhas". "cecídias" ou "tumores vegetais" em plantas nativas da flora do Brasil. Leandra 8-9: 5-35.

PIZZOLATO, P. 1964. Histochemical recognition of calcium oxalate. J. Histochem. Cytochem. 12: 333336.

PRICE, P. W., FERNANDES, G. W. \& WARRING, G. L. 1987. Adlaptive nature of insect galls. Envirom. Entomol. 16: 15-24.

ROHFRITSCH, O. 1980. Relations hôte-parasite au début de la cécidogenèse du Hartigiola annulipes Hartig su le Hêtre. Bull. Soc. bot. Fr. Actual Botanique 127: 199-207.

ROHFRITSCH, O. 1992. Patterns in gall development. In J. D. Shorthouse \& O. Rohfritsch (eds). Biology of insect-induced galls. Oxford University Press. New York, p. 60-86.

SILVER, V. L. 1969. Demonstration of calcium oxalate crystals in plant tissues by the Pizzolato (AgNO3.H2O2) method. Stain Techlnol. 44: 257-259.

TAVARES, J. S. 1920. Cecidologia brasileira. Cecídias que se criam em plantas das famílias Leguminosae, Sapotaceae, Lauraceae, Myrtaceae, Punicaceae, Umbelliferae, Loranthaceae, Apocynaceae, Urticaceae, Salicaceae e Gramineae. Brotéria, Sér: Zool. 18: 82-125.

TAVARES, J. S. 1922. Cecidologia brazileira - As restantes famílias. Brotérici, Sér. Zool. 20: 5-48b. 